\title{
PRODUCTION OF POPPED SORGHUM WITH USING MICROWAVE TREATMENT
}

\begin{abstract}
This article describes main methods of using the method of microwave treatment in food industry and in grain processing in particular. Main principles of this technology as well as using this technological approach for popping grain have been considered. Scientific works aimed at researching possibility of using microwave radiation for preparation of popped grains have been reviewed. Factors influencing the process of preparing popped grain have been considered; these factors include morphological structure and chemical composition of grains.

Sorghum is one of the main food crops in the world agriculture (especially in such countries as India, PRC, Ethiopia, Morocco, Sudan) taking agriculture areas of about 50 million hectares. Popularity of growing sorghum in Ukraine can be explained in particular through its ability to produce high yields in warm and dry climatic conditions. Human organism does not perform absorption of nutrients from sorghum in full amount due to the fact that there are kafirins in endosperm of sorghum and these substances agglutinate starch granules. That is why a peculiar attention in this article has been paid to influence of microwave treatment on digestibility of sorghum starch and proteins.

The goal of carrying out scientific researches consisted in defining parameters of microwave radiation influence on the process of popping sorghum grains depending on grain particle size (fractional composition) as well as in developing a technological scheme of popping sorghum.

The process of microwave treatment of sorghum grains has been researched. Microwave processing of grains was performed in microwave oven with working frequency of 2,450 MHz and the following levels of power were applied: 450, 600, 700 W with exposure time 120-150 s. Grain sorghum "Fulgus" was used for carrying out the research. Effect of microwave radiation on the start of the popping process and on yield of popped sorghum previously divided into two fractions has been determined. In addition to this influence of microwave treatment on increasing the volume of coarse fraction and fine fraction sorghum grains has been determined.

A technological scheme of producing popped sorghum with using microwave treatment has been developed. This technological scheme includes the following operations: cleaning grains from various contaminations, calibration, conditioning, microwave treatment, cooling, optical sorting, packing. The technological process within the developed technological scheme has been described and a clear sequence of operations for preparation of popped sorghum has been provided. The proposed technological scheme has two variants of execution. The first variant consists in using air-sieve separators and concentrators or combined machines for cleaning and calibration of sorghum grains. The second variant consists in combining procedures of cleaning and calibration into a single stage with a help of up-to-date technological equipment.
\end{abstract}

Key words: sorghum, popped grains, microwave treatment, technology of popping sorghum

\section{Introduction}

Recently demand for food products made with a use of popped grains has been growing. For example during the recent years (2011-2016) popcorn production has increased by $20 \%$ [1]. Preparation of popped grains (popping) is a simultaneous process of starch gelatinization and expansion. During this process short period of time grains are subjected to influence of high temperatures [2]. Upon popping steam produced inside grains by means of instantaneous heating suddenly expands endosperm and breaks the external envelope. In the process of popping the product is almost sterilized and a great part of its microflora is destroyed. Popping also improves digestibility of starch as far as it includes starch gelatinization and partial degradation of dietary fibers [2]. Popped grains received in the result of popping are a pre-cooked i.e. ready-to-eat product which can be used in snack foods as well as a base for development of new functional food products (including dietary products). It should be pointed out that not any grain or seed can be popped. Usually corn and rice are used for preparing products of this kind. Separate published researches inform about possibility to prepare popped grains (seeds) of other crops including in particular sorghum [2-4].

Sorghum is an important agricultural crop taking the third position in the world after wheat and rice [4]. In
Africa and India as well as in Eastern Asia countries it is the main agricultural crop. Today sorghum is a promising crop to be grown in the steppe zone of Ukraine which is confirmed through year-after-year increase of its plantations. The main areas under these crops are presented in dry regions such as Mykolayiv, Kherson, Odessa or Dnipropetrovsk one [5]. Researches [2-4] confirm that sorghum grains can be popped and that is the basis for carrying out further researches and determining optimal methods and parameters for the popping.

There are various methods of popping grain and in particular these methods include [3]:

- traditional method of dry heat;

- processing with heated salt;

- processing with heated air in a fluidized bed;

- frying in a hot oil;

- microwave treatment.

During the recent years in many spheres the use of technologies based on processing food in electromagnetic field of microwave treatment is steadily increasing [5]. And due to this fact scientific and technical progress is accelerated, and production process efficiency and quality of final products are improved. This technology is used for heating and defrosting [7], drying [8], disinfection (decontamination) [9-11] and popping of corn, rice, sorghum, buckwheat, amaranth [2- 


\section{$4,12]$ as well as other agricultural crops.}

One of main advantages of microwave treatment consists in significant time saving as far as the process of processing is taking place very quickly [13]. In addition to that this technology gives an opportunity to better preserve nutrients, vitamins and minerals which appears to be quite a difficult task in case of using another method of processing. Heating of grains is performed due to absorption of energy delivered by microwaves [7]. Also this method differs from traditional kinds of heat treatment and this difference consists in uniformity of heating.

The aim of carrying out scientific researches consisted in defining parameters of microwave radiation influence on the process of preparing popped sorghum grains depending on grain particle size (fractional composition) as well as in developing a technological scheme of preparing popped sorghum.

\section{Materials and methods of research}

For carrying out research grain sorghum "Fulgus" was used with moisture level 13.0\%, volumetric weight $870 \mathrm{~g} / \mathrm{l}$, weight of 1,000 grains $32 \mathrm{~g}$. According to organoleptic quality indexes grains met the requirements of the current regulatory documents (DSTU 4962:2008 Sorghum. Specifications). According to its chemical composition the grains included $73 \%$ of starch, $8 \%$ of crude protein and $2 \%$ of crude fiber.

At the beginning of research sorghum grain was cleaned from garbage and grain impurities and then it was previously divided into two fractional groups by means of sieving with a help of grid sieves (diameter of holes $5.0 \mathrm{~mm}, 4.0 \mathrm{~mm}, 3.0 \mathrm{~mm}$ ). The first fractional group - passing through $\varnothing 5 \mathrm{~mm}$ and sieved off with $\varnothing 4 \mathrm{~mm}$; the second fractional group - passing through $\varnothing 4 \mathrm{~mm}$ and sieved off with $\varnothing 3 \mathrm{~mm}$.

Microwave treatment of grains was performed in a microwave oven (Samsung, Korea) with working frequency of $2,450 \mathrm{MHz}$ and the following levels of power were applied: $450,600,700 \mathrm{~W}$ with exposure time $120-150 \mathrm{~s}$

After carrying out the process of popping popped grains were separated from non-popped ones. Grains were considered completely popped if nonpopped endosperm could not be observed during visual examination. Popping yield, PY, \% was calculated with a help of the following formula (1.1):

$$
P Y=\frac{n_{1}}{n_{1}+n_{2}+n_{3}},
$$

where $n_{1}$ - amount of popped grains, $\mathrm{g}$;

$n_{2}$ - amount of partially popped grains, $\mathrm{g}$;

$n_{3}$ - amount of non-popped grains, $g$.

Volume expansion ratio was determined as ratio of native sorghum volume to the volume of popped sorghum. Sensory evaluation of popped grain quality were determined according to the current regulatory documents (DSTU 2903:2005 Food concentrates. Breakfast Cereal. General Specifications).

\section{Results of research and discussion}

Preparation of popped grains is influenced by a group of factors which can be divided into those conditioned by the anatomic structure of grains and their chemical composition and those related with parameters of popped grain processing (using this or that method). The main parameter of microwave processing is power of radiation. In case of processing sorghum grains with microwave energy influence of grain size on characteristics of the process has been researched. Results of these researches are presented in Fig. 1, 2. It has been determined that under the same conditions sorghum grains of the coarse fraction have a shorter resistance time and at the same time sorghum grains of the coarse fraction have a better result of popped grains in comparison with fine fraction grains.

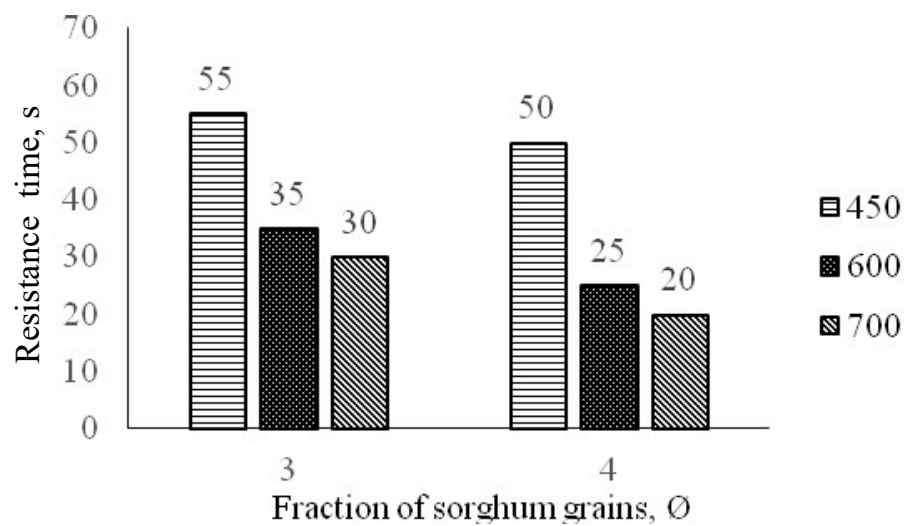

Fig. 1 -Resistance time of popping sorghum depending on power of microwave radiation

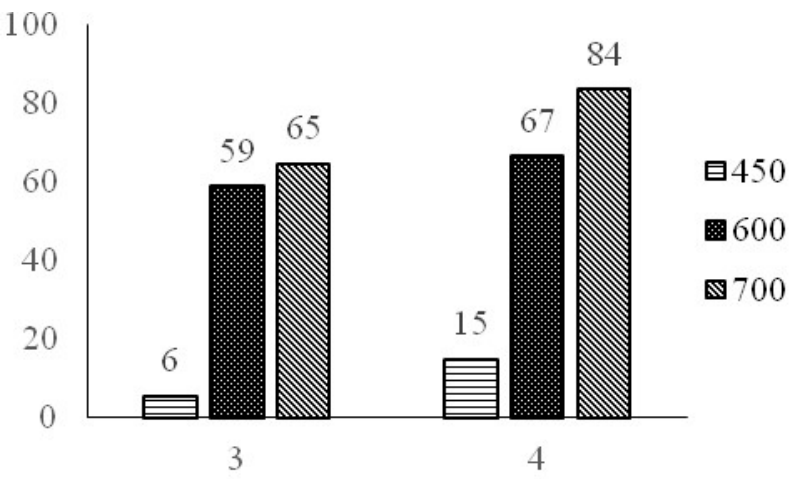

Fraction of sorghum grains, $\varnothing$

Fig. 2 - Yield of popped sorghum depending on power of microwave radiation

Process of popping significantly depends on grain morphology and composition. Properties of grain crops (such as their size, shape and density) also have an influence on the volume of expansion. The determinative structural components of grain anatomic structure with pop properties include pericarp and endosperm. It has been determined that volumetric increase of popped grains has a positive correlation with ratio of horny endosperm to floury endosperm [14]. The decisive role in the process of nucleation belongs to hilum of sorghum grains which is the nucleation center of horny endosperm starch granule [15]. Sorghum of coarse fraction appears to be more completed and so it has a greater amount of horny endosperm and this fact can obviously explain its better popping in comparison with sorghum grains of the fine fraction group. 
Influence of microwave treatment on the volume expansion ratio of sorghum grains (the coarse fraction group and fine fraction group) is presented in Fig. 3.

Fig. 3 shows that intensity of microwave radiation has stronger influence on endosperm expansion in case with sorghum grains from the fine fraction group. It has been determined that sorghum grains of fine fraction have higher volume expansion ratio in comparison with sorghum of coarse fraction in case of using high power $(600,700 \mathrm{~W})$, but in case with coarse fraction indexes the increase is insignificant.

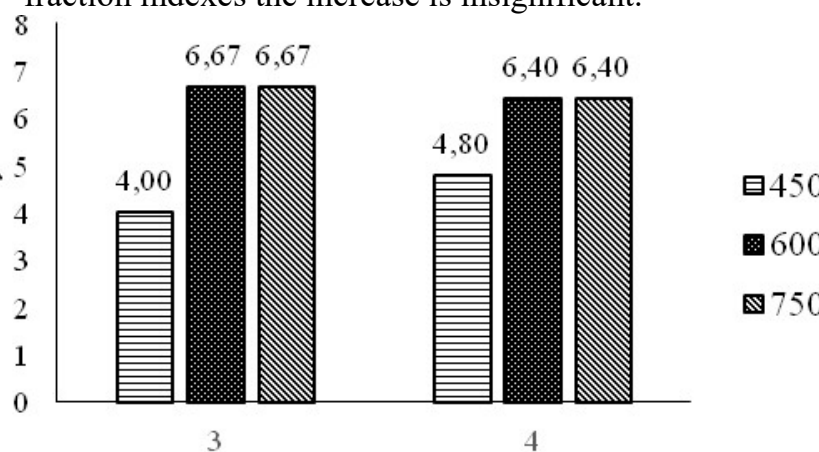

Fraction of sorghum grains, $\varnothing$

Fig. 3 - Influence of microwave radiation intensity on volume expansion ratio of popped sorghum

Table 1 - Sensory evaluation of popped sorghum made with use of microwave treatment

\begin{tabular}{|c|c|c|}
\hline \multirow{2}{*}{ Characteristic } & \multicolumn{2}{|c|}{ Power, W: } \\
\hline & 450 & 700 \\
\hline \multicolumn{3}{|c|}{ fraction $\varnothing 3$} \\
\hline Appearance & \multicolumn{2}{|c|}{$\begin{array}{c}\text { various in size and shape; edges are } \\
\text { slightly torn }\end{array}$} \\
\hline Color & $\begin{array}{c}\text { white with light } \\
\text { brown tint }\end{array}$ & $\begin{array}{l}\text { white with } \\
\text { some black } \\
\text { spots }\end{array}$ \\
\hline Aroma (odor) & $\begin{array}{l}\text { pleasant aroma } \\
\text { typical for popped } \\
\text { sorghum; without } \\
\text { foreign odors }\end{array}$ & $\begin{array}{l}\text { slight odor of } \\
\text { smoke }\end{array}$ \\
\hline Taste & $\begin{array}{l}\text { a typical slightly } \\
\text { sweat taste }\end{array}$ & $\begin{array}{c}\text { barely } \\
\text { noticeable burnt } \\
\text { taste }\end{array}$ \\
\hline Structure & \multicolumn{2}{|c|}{ Crispy, porous } \\
\hline \multicolumn{3}{|c|}{ fraction $\varnothing 4$} \\
\hline Appearance & \multicolumn{2}{|c|}{$\begin{array}{l}\text { various in size and shape; edges are } \\
\text { slightly torn }\end{array}$} \\
\hline Color & $\begin{array}{c}\text { white with light } \\
\text { brown tint }\end{array}$ & $\begin{array}{c}\text { white with } \\
\text { some black } \\
\text { spots }\end{array}$ \\
\hline Aroma (odor) & $\begin{array}{l}\text { pleasant aroma } \\
\text { typical for popped } \\
\text { sorghum; without } \\
\text { foreign odors }\end{array}$ & $\begin{array}{l}\text { slight odor of } \\
\text { smoke }\end{array}$ \\
\hline Taste & $\begin{array}{l}\text { a typical slightly } \\
\text { sweat taste }\end{array}$ & $\begin{array}{c}\text { barely } \\
\text { noticeable burnt } \\
\text { taste }\end{array}$ \\
\hline Structure & \multicolumn{2}{|c|}{ crispy, porous } \\
\hline
\end{tabular}

A positive characteristic of the considered technology is that according to results of researches $[2,3]$ microwave treatment improves digestibility of starch. Under influence of microwave radiation starch gelatinization takes place with formation of soluble amylose [3]. Usually starch granule in sorghum grains is surrounded with protein matrix and that makes it inaccessible for digestive enzymes of the human organism. During microwave treatment of starch the granules burst and create foamy structure which destroys protein matrix of starch. This modified structure of starch becomes accessible for digestive enzymes of human organism and so digestibility of the product received from sorghum grains is improved. In the result of the popping process phytic acid content in sorghum grains is decreased and this improves protein digestibility [4]. So, in the result of microwave treatment digestibility of sorghum grains is improved. At the same time remains of phytic acid left after the processing can help to decrease the level of peroxidation and so shelf life of the product can be prolonged [3]. A high level of sorghum digestibility can be considered as a partial justification of traditional using products made of these grains as easily digestible food for children and elderly people.

Each sample of prepared popped sorghum grains made from coarse and fine fractions was subjected to sensory evaluation. Results of these examinations are presented in Table 1.

The Table 1 shows that microwave treatment at $700 \mathrm{~W}$ has a negative influence on sensory characteristics of popped sorghum. At the same time a high quality of the final product can be achieved when using microwave heating at 450 and $600 \mathrm{~W}$. In case of using these modes of processing organoleptic properties of popped sorghum grains do not differ significantly. So, it is namely sensory characteristics of popped sorghum grains depending on power of microwave treatment that appear to be a limiting factor in the technology under consideration.

In the result of research it has been determined that the most reasonable variant consists in preparing popped sorghum from grains of coarse fraction. In case of processing such grains popping yield can be increased with a shorter resistance time. Sorghum grains of fine fraction have higher volume expansion ratio but the difference is not significant. Also, it is recommended to use microwave heating at $600 \mathrm{~W}$. This mode ensures maximally balanced characteristics of the process and a high quality of the final product.

The developed technological scheme of producing popped sorghum by means of microwave treatment is presented in Fig. 4. Execution of the following operations is proposed: cleaning grains from various contaminations, calibration, conditioning, microwave treatment, cooling, optical sorting, and packing.

Technological process of popping sorghum by means of microwave treatment is executed in the following way. Sorghum from storage warehouses is directed for the procedure of cleaning from various contaminations which differ from grains of the main crops in density, geometric parameters and aerodynamic characteristics. 


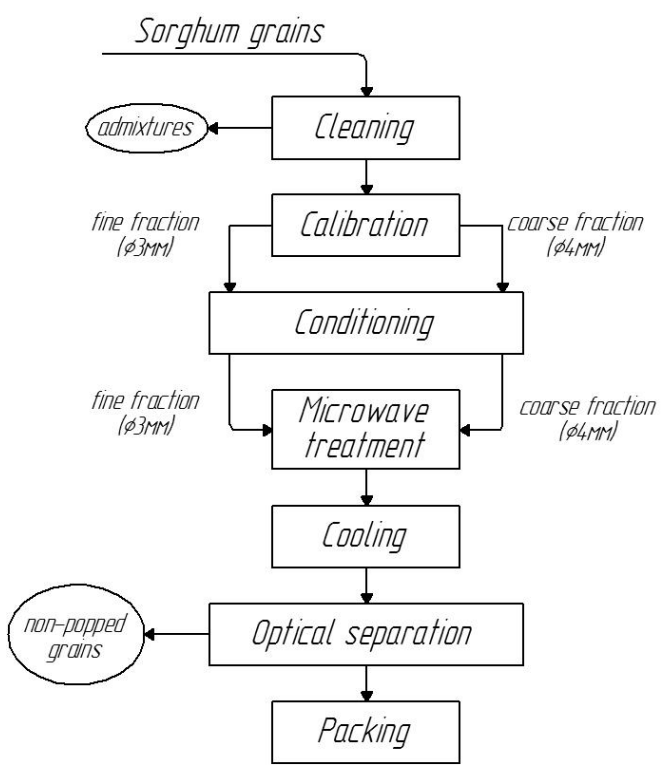

Fig. 4-Technological scheme of producing sorghum popped grains by means

Cleaned sorghum is directed for calibration where the grains are divided into two fractions (by size): coarse fraction and fine fraction. The coarse fraction includes grains sieved off with round holes of $4 \mathrm{~mm}$ in diameter; and the fine fraction includes grains which passed holes of $4 \mathrm{~mm}$ in diameter but were sieved off with holes of $3 \mathrm{~mm}$ in diameter. A possible variant consists in combining operations of cleaning and calibration into a single stage with a help of up-to-date technological equipment represented as combined graincleaning machines combining functions of separator, rubble separator and concentrator.

The calibrated sorghum grains are in two separate flows delivered to vortex humidifiers for conditioning. Calculation of moisture volume depends on the initial humidity level of grain delivered for treatment.

Humidified sorghum grains are in separate fractions directed to storage bins located before the microwave equipment and after that the grains are delivered for microwave treatment (through diverter valves). Under influence of microwave heating sorghum grains are subjected to significant structural changes: energy is accumulated in the processed grains and this leads to popping. In the result of the popping grain pericarp is destroyed, starch is expanded and popped sorghum is received.
Popped grains and non-popped grains are transported by a conveyor to storage bins before coming to an optical sorter and during this transportation they are cooled with atmospheric air. On the stage of optical separation non-popped grains are separated from popped ones and directed to a storage bin. Subsequently this byproduct can be used as fodder. Then separated popped grains are directed for packing and storage.

Conclusions. Perspectives of using microwave treatment for grain processing industry have been proved. The main advantages of this technology consist in time reduction of the technological process, ability to save resources and preserve key nutrients of the product after treatment.

Effect of grain size on characteristics of sorghum microwave processing has been researched. It has been determined that under the same conditions sorghum of the coarse fraction has lesser resistance time and at the same time sorghum of the coarse fraction has a better popping yield in comparison with fine fraction grains. It has been determined that intensity of microwave radiation has a stronger influence on endosperm expansion in case with fine fraction sorghum (in comparison with coarse fraction grains). However, fine fraction sorghum has a higher volume expansion ratio in comparison with coarse fraction grains (in case of using power at $600-700 \mathrm{~W}$ ), but the difference is insignificant.

After microwave treatment at 700 W deterioration of sensory characteristics of popped sorghum takes place. So, it is namely sensory accessibility of popped sorghum grains depending on power of microwave treatment that appear to be a limiting factor in the technology under consideration.

The developed technological scheme has two variants of execution. The first variant consists in using air-sieve separators and concentrators or combined machines for cleaning and calibration of sorghum grains. The second variant presupposes combining procedures of cleaning and calibration into a single stage with a help of up-to-date technological equipment e.g. combined graincleaning machines. This equipment includes functions of separator, rubble separator and concentrator therefore it significantly reduces metal and energy consumption of the production line. The second variant is proposed as the most cost-effective and resource-saving option for implementation of the proposed technology.

\section{REFERENCES}

1. Bischof T. From grains and nuts to convenient snack bars. Diagram. The Buhler magazine. 2017. №175. P. 34-35.

2. Mishra G., Joshi D.C., Mohapatra D. Optimization of pretreatments and process parameters for sorghum popping in microwave oven using response surface methodology. J Food Sci Technol. 2015. Vol. 52, №12. P. 7839-7849.

3. Mishra G., Joshi D.C., Panda B.K. Popping and puffing of cereal grains: a review. Journal of grain processing and storage. 2014. Vol. 1, №2. P. 34-46.

4. Saravanabavan S.N., Shivanna M.M., Blattacharya S. Effect of popping on sorghum starch digestibility and predicted glycemic index. J. Food Sci. Technol. 2013. Vol. 50, №2. P. 387-392.

5. Bazaliy V. V., Zinchenko O.I., Lavrinenko O.Y. Roslinnitstvo: pidruchnik. Herson : vydavets Grin D. S. 2015.52 p.

6. Venkatesh M.S., Raghavan G.S. An Overview of Microwave Processing and Dielectric Properties of Agri-Food Materials. Biosystems Engineering. 2004. Vol. 88, №1. P. 1-18.

7. Ruschits A.A., Scherbakova E.I. Primenenie SVCh-nagreva v pischevoy promyishlennosti i obschestvennom pitanii. Vestnik YuUrGU. Seriya «Pischevyie i biotehnologii». 2014. №1. P. 9-15.

8. Altuhov I.V., Ochirov V.D. Analiz sposobov sushki pischevyih produktov. Vestnik Irkutskoy gosudarstvennoy selskohozyaystvennoy akademii. 2009. №36. P. 16-21.

9. Cherkasova E.I. Ispolzovanie SVCh-polya dlya obespecheniya mikrobiologicheskoy bezopasnosti produktov rastitelnogo proishozhdeniya. Vestnik YuUrGU. Seriya: «Pischevyie i biotehnologii». 2014. №1. P. 67-71. 
10. Yusupova G.G., Yusupov R.H. Elektrotermicheskoe vozdeystvie energiey SVCh-polya-ekologicheskoe reshenie problemyi kachestva i bezopasnosti zernovogo syirya Vestnik FGOU VPO MGAU. 2012. №1. P. 9-12.

11. Yusupova G.G. Dekontaminatsiya zerna i produktov ego pererabotki ot toksikogennyih gribov energiey SVCh-polya Vestnik FGOU VPO MGAU. 2008. №4. P. 19-22.

12. Lara N., Ruales J. Popping of amaranth grain (Amaranthus caudatus) and its effect on the functional, nutritional and sensory properties. Journal of the Science of Food and Agriculture. 2002. Vol. 82, №8. P. 797-805.

13. Lisovoy V.V., Pershakova T.V., Kornen N.N. Primenenie EMP SVCh v tehnologiyah pererabotki rastitelnogo syirya $i$ vtorichnyih resursov. Politematicheskiy setevoy elektronnyiy nauchnyiy zhurnal Kubanskogo gosudarstvennogo agrarnogo universiteta. 2016. №118. P. 1350-1362.

14. Kuianov Y. Y., Mykolenko S.Y. Tehnologichni aspekti otrimannya «zirvanih» zeren NVCh-vyprominyuvannyam. Harchova promislovist. 2017. №22. P. 40-48.

15. Hosni R.K. Zerno i zernoproduktyi (Seriya: Nauchnyie osnovy i tehnologiya): per. $s$ angl. pod obsch. red. N.P. Chernyaeva. SPb: Professiya. 2006. 336 p.

\title{
УДК 664.696.2
}

\section{Д.О. ТИМЧАК, магістрант; С.Ю. МИКОЛЕНКО, канд.техн.наук доцент; Ю.Ю. КУЯНОВ, канд.техн.наук, доцент Дніпровський державний аграрно-економічний університет, м. Дніпро ОТРИМАННЯ ПОВІТРЯНОГО СОРГО ШЛЯХОМ НАДВИСОКОЧАСТОТНОГО ОПРОМІНЕННЯ}

\begin{abstract}
Анотація
У статті описано основні шляхи застосування методу надвисокочастотної обробки в харчовій промисловості, і в зернопереробній галузі зокрема. Розглянуто основні принципи даної технологї та перспективи використання ї̈ для отримання повітряних зерен. Здійснено огляд наукових праиь, спрямованих на дослідження можливості використання надвисокочастотної обробки для отримання повітряних зерен. Розглянуто фактори впливу на процес отримання повітряних зерен, серед яких морфологічна будова та хімічний склад зерна.

У світовому землеробстві сорго є однією з основних продовольчих культур, особливо в таких краӥнах як Індія, КНР, Ефіопія, Марокко, Судан, займаючи площі близько 50 млн га. Популярність вирощування сорго в Україні обумовлена, зокрема, його здатністю давати високі врожаї в теплих, сухих регіонах. Засвоєння організмом людини поживних речовин сорго в повному обсязі не відбувається, оскільки у роговидному ендоспермі сорго присутні некафірини (альбуміни, глобуліни та глютеліни), які «склеюють» гранули крохмалю. Тому в статті приділено увагу впливу надвисокочастотної обробки на засвоюваність крохмалю та білків зерна сорго.

Метою проведення досліджень було визначення впливу параметрів надвисокочастотного опромінення на прочес отримання повітряних зерен сорго залежно від фракційного складу та розробка технологічної схеми виробництва повітряного сорго.

Проведено дослідження прочесу надвисокочастотного опромінення зерна сорго. Обробку надвисокочастотним опроміненням здійснювали у мікрохвильовій печі Samsung (Корея) із робочою частотою 2450 МГи та застосовували наступні рівні потужності: 450, 600, 700 Вт за тривалості прочесу 120-150 с. Для проведення досліджень використовували сорго зернове "Фулгус». При иьому визначено вплив інтенсивності надвисокочастотного опромінення на час початку процесу «зривання» та вихід повітряного сорго, попередньо розділеного на дві фракції: крупну $i$ дрібну. Також було встановлено вплив мікрохвильового опромінення на збільшення об'єму зерна сорго дрібної та крупної фракиій.

Було розроблено технологічну схему виробниџтва повітряних зерен сорго иляхом надвисокочастотного опромінення. До складу операцій даної технологічної схеми входять наступні: очищення зерна сорго від різного виду домішок, калібрування, кондиціонування, надвисокочастотна обробка, охолодження, фотосепарування, пакування. Описано здійснення технологічного прочесу в розробленій технологічній схемі та приведено чітку послідовність операчій для отримання повітряного сорго. Запропонована технологічна схема має два варіанти виконання. Перший варіант полягає у використанні повітряно-ситових сепараторів та концентраторів або комбінаторів для очищення i калібрування зерна сорго. Другий варіант полягає в об'єднанні операцій очищення та калібрування в один етап за допомогою застосування сучасного технологічного обладнання.
\end{abstract}

Ключові слова: зерно сорго, повітряні зерна, поппінг, надвисокочастотна обробка, технологія отримання повітряного сорго.

\section{ЛITEPATУРА:}

1. Bischof T. From grains and nuts to convenient snack bars. Diagram. The Buhler magazine. 2017. №175. P. 34-35.

2. Mishra G., Joshi D.C., Mohapatra D. Optimization of pretreatments and process parameters for sorghum popping in microwave oven using response surface methodology. J Food Sci Technol. 2015. Vol. 52, №12. P. 7839-7849.

3. Mishra G., Joshi D.C., Panda B.K. Popping and puffing of cereal grains: a review. Journal of grain processing and storage. 2014. Vol. 1, №2. P. 34-46.

4. Saravanabavan S.N., Shivanna M.M.,Blattacharya S. Effect of popping on sorghum starch digestibility and predicted glycemic index. J. Food Sci. Technol. 2013. Vol. 50, №2. P. 387-392.

5. Базалій В.В., Зінченко О.І., Лавриненко О.Ю. Рослинництво: підручник. Херсон: видавець Грінь Д.С. 2015.52 с.

6. Venkatesh M.S., Raghavan G.S. An Overview of Microwave Processing and Dielectric Properties of Agri-Food Materials. Biosystems Engineering. 2004. Vol. 88, №1. P. 1-18.

7. Рущии А.А., Щербакова Е.И. Применение СВЧ-нагрева в пищевой промышленности и общественном питании. Вестник ЮУрГУ. Серия «Пищевые и биотехнологии». 2014. №1. С. 9-15. 
8. Алтухов И.В., Очиров В.Д. Анализ способов сушки пищевых продуктов. Вестник Иркутской государственной сельскохозяйственной академии. 2009. №36. С. 16-21.

9. Черкасова Э.И. Использование СВЧ-поля для обеспечения микробиологической безопасности продуктов растительного происхождения. Вестник ЮУрГУ. Серия: «Пищевые и биотехнологии». 2014. №1. С. 67-71.

10. Юсупова Г.Г., Юсупов Р.Х. Электротермическое воздействие энергией СВЧ-поля - экологическое решение проблемы качества и безопасности зернового сырья Вестник ФГОУ ВПО МГАУ. 2012. №1. С. 9-12.

11. Юсупова Г.Г. Деконтаминация зерна и продуктов его переработки от токсикогенных грибов энергией СВЧ поля Вестник ФГОУ ВПО МГАУ. 2008. №4. С. 19-22.

12. Lara N., Ruales J. Popping of amaranth grain (Amaranthus caudatus) and its effect on the functional, nutritional and sensory properties. Journal of the Science of Food and Agriculture. 2002. Vol. 82, №8. P. 797-805.

13. Лисовой В.В., Периакова Т.В., Корнен Н.Н. Применение ЭМП СВЧ в технологиях переработки растительного сырья и вторичных ресурсов. Политематический сетевой электронный научный журнал Кубанского государственного аграрного университета. 2016. №118. С. 1350-1362.

14. Куянов Ю. Ю., Миколенко С.Ю. Технологічні аспекти отримання «зірваних» зерен НВЧ-випромінюванням. Харчова промисловість. 2017. №22. С. 40-48.

15. Хосни Р.К. Зерно и зернопродукты (Серия: Научные основы и технология): пер. с англ. под общ. ред. Н.П. Черняева. СПб: Профессия. 2006. 336 с.

Надійшла 11.05.2018. До друку 04.06.2018

Адреса для переписки:

dmytrotymchak@gmail.com

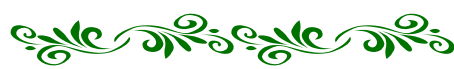

\title{
УДК: 664.784.8:[633.15:54.021] \\ SOTS S.M., Ph.D., Ass. Professor, Dean of the Faculty of Grain and Grain Business Technologies BNYIAK O.V., postgraduate student, VALEVSKAYA L.O., Ph.D., Ass. Professor of the \\ Department of Technology for Storage of Grain \\ Odessa National Academy of Food Technologies, Odessa \\ USE OF CORN GRAIN IN PRODUCTION OF FOOD PRODUCTS
}

\begin{abstract}
In Ukraine, the following basic crops are used as raw materials for the production of cereals, flour, flakes: wheat, barley, buckwheat, oats, corn, rice, millet, peas. The volume of world grain production in recent years has grown significantly.

In Ukraine, corn is the main fodder crop, and only in small quantities is used as food. Corn takes the leading place among the main grain crops in the world agricultural production. The production of corn for grain is concentrated in warm regions. In some regions, corn is the basis of the traditional food of the population, but mostly it is part of the feed in the feeding of farm animals. Corn does not accumulate nitrates and is an environmentally friendly product. Corn is a plant of versatile use.

Currently, corn is one of the most important food crop cultivated by man. As to the largest producers of this cereal are the United States, China, Mexico, India, Brazil, Argentina, Indonesia, South Africa, France and Italy.

Today, about 3500 food and technological products are made from corn. Corn is able to largely meet the needs of animal husbandry, its share is almost $30 \%$ in the composition of concentrated feed. Corn is used in food, starch, brewing and alcohol industries. With the advent of new directions in the development of biotechnology in the world, the importance of this culture is growing even more.

In the countries of the European Union in recent years, the production of various types of fuels from plant materials biodiesel, bioethanol, biomethanol and biofuel is actively developing. Bioethanol is obtained from all cultures with a high content of starch and sugar, for example, potatoes, sugar beet, corn, various types of cereals, and therefore a significant expansion of the acreage under corn is projected.

In the article volumes of corn grain collection in different years in Ukraine for the production of cereals and groats are considered. Various types of maize as a perspective raw material for use in the food industry are considered. It is shown that two subspecies of maize are most widespread in Ukraine - a dentate (large grain of elongated form) and siliceous (a rounded grain). The presence of vitamins $B(B 1, B 2, P P)$, calcium, magnesium, phosphorus and iron, as well as trace elements (copper, nickel, etc.) in maize makes it possible to recommend corn products as a separate product or in combination with other people with blood diseases, allergies, diabetes mellitus, obesity and other forms of metabolic disorders and pathology of the gastrointestinal tract.

The authors analyzed the chemical composition of corn grain of various botanical groups intended for the production of cereals and products from them. The composition of micro- and macronutrients of corn groats used in the production of food products (snacks, breakfast cereals, instant cereals, cereals, etc.) is given.
\end{abstract}

Key words: corn, production, processing, chemical composition, corn grits.

The technologies of obtaining products from grains are the most common and varied, since grain is the main and indispensable source of food products. Cereal products contain a complete set of nutrients necessary for normal functioning of human body. They are the most valuable source of carbohydrates, proteins, macro- and micronutrients, vitamins, enzymes, food fibers, phospholipids and other biologically active substances. At the same time, production of cereal products is the cheapest in comparison with production of other food products.

Due to the use of grain products in food, up to $40 \%$ of need for vitamins in B group is covered and up to 